\title{
Paths and Challenges of New Technologies: The Case of Nanotechnology-Based Cosmetics Development in Brazil
}

\author{
Denise Barbieux * and Antonio Domingos Padula * (i) \\ School of Management and Innovation Research Center (NITEC), Federal University of Rio Grande do \\ Sul (UFRGS), Porto Alegre, RS 90010-460, Brazil \\ * Correspondence: dedsbar@gmail.com (D.B.); antonio.padula@ufrgs.br (A.D.P.); \\ Tel.: +55-(51)-3308-38-15 (A.D.P.)
}

Received: 14 March 2018; Accepted: 4 May 2018; Published: 11 May 2018

\begin{abstract}
New technologies have challenges to overcome when applying it to new products. New products depend on the technological and market novelties. Therefore, the term product innovativeness is defined as the technological and market degree of novelty. For several industries, the nanotechnology has been the latest technology, and it has also been included in Brazilian government strategic agenda. Considering the importance of new technologies and innovation, we describe the paths and challenges of nanotechnology-based cosmetics development to achieve product innovativeness. Opposing the new product development (NPD) mainstream based on efficiency, we used the evolutionary approach by highlighting the novelties. We describe three NPD stages (conception, operationalization, nd launch). For empirical evidence, we chose two Brazilian emblematic cases (suppliers for cosmetics industry) that domain nanotechnology. One case scans more potential market novelties and consequently produces indigenous nanotechnology for international industries such as cosmetics, food, and textile. The second case represents the new technology limited by the application in cosmetics. New technologies are not an innovation guarantee. Market demands must be identified in the early stage of NPD. When the focus is the novelty, the NPD evolutionary approach is useful.
\end{abstract}

Keywords: nanotechnology; cosmetics industry; product innovativeness; innovation; New Product Development; Small and Medium Enterprises

\section{Introduction}

Innovation is the inevitable outcome of the very survival of the firm. The affirmation is particularly important in turbulent and competitive markets. When the offer is greater than the demand, product development becomes more complex. The premise of "doing more of the same" is no longer an alternative for firms. They have to do something different to achieve novelty, in which the technology becomes central.

The neo-Schumpeterian perspective suggests that technology is appropriated by the firm and can be learned (Cohen and Levinthal 1990; Zahra and George 2002; Escribano et al. 2009), accumulated (Dosi 1988; Lall 1992; Bell and Pavitt 1995; Figueiredo 2004; Kim and Nelson 2005; Rush et al. 2007) and changed (Nelson and Winter 2005; Teece et al. 1997; Eisenhardt and Martin 2000; Teece 2007). Technological innovation has been characterized as the adaptation, improvement or development of new products or processes (Lall 1992; Bell and Pavitt 1995) and the degree of technological innovation has been related to the technological capability of the firm.

New technologies offer challenges to the firm that need to be overcome. To improve technological capabilities and consequently the degree of innovation, it is necessary to learn about new technology, 
accumulate new knowledge and apply it. The application results in new product improvement or creation.

In Brazil, although most firms declare they create new products, the reality does not support this argument. According to the latest Survey of Technological Innovation (PINTEC) from 2012 to 2014, $18.3 \%$ of Brazilian industrial companies have engaged in product innovation. However, only $3.8 \%$ of the products created were new for the domestic market (IBGE Instituto Brasileiro de Geografia e Estatística). This data reveals the gap between product development and product innovation.

It is not an easy task to define the degree of innovation on new products. The terms 'innovation' and 'product innovation' have been used as buzzwords. The term 'innovativeness' has been used interchangeably with the term 'innovation' and presents inconsistencies in its operationalization (Garcia and Calantone 2002; Schultz et al. 2013). Even so, for several authors, the product innovativeness represents a measure with respect to the technological and market degree of novelty embedded into the product. The incorporation of the contents (technological and market) takes place through the process of new product development to transform ideas into a marketable product (Loch and Kavadias 2008).

The nanotechnology has been the state-of-the-art on technology for various industrial sectors such as chemicals, pharmaceuticals, and cosmetics. Nanotechnology has been included in the Brazilian government strategic agenda since 2001 to support new technologies in Brazil. It requires a high level of knowledge and there are some Brazilian firms that stand out in the cosmetics market, for both domestic and international ones. Considering the worldwide importance of nanotechnology and the gap between product development and product innovativeness, the purpose of this paper is to describe the paths and challenges of new technologies development. Two Brazilian cases of nanotechnology-based product developments are described, and their product innovativeness is classified in order to establish the paths and disclose the challenges of it.

In the following sections, we discuss the novelty of new product development process and product innovativeness, as well as the Brazilian cosmetics industry in an innovativeness context. Then, we describe the research method and the two case studies from Brazilian nanotechnology suppliers for the cosmetics industry. Following that, the interview analyses and the results are shown. In the final section, we discuss our findings and present the conclusions, conceptual and managerial implications.

\section{Overview of the Literature}

\subsection{Novelty}

There is no doubt that innovation, in essence, is defined as something new. However, due to the multidisciplinary theme, the word "new" raises questions such as: what is new? how to develop it? how much is new? for whom? how to measure it? The answers to these questions are as complex as the phenomenon itself and require different theoretical approaches.

The terms "disruptive innovation" (Christensen 1997), "breakthrough" (Stefik and Stefik 2004) and "radical innovation" (Garcia and Calantone 2002) have been used to define when something novel is created to an unrecognized demand. They represent the discontinuities of both the market and technological practices (Garcia and Calantone 2002; Gurtner and Reinhardt 2016). The moment after the innovation, the firm benefits from a temporary monopoly (Schumpeter 1984) in which the firm achieves the highest positive return because there is no comparison among the new products from the other firms on the marketplace. This monopoly power is temporary and erodes when imitations appear. Incremental innovation or new technologies can threat profitability or even outdate the existing product in the market (Garcia and Calantone 2002; Stefik and Stefik 2004)

The novelty arises from the ideas that are different from those existing (Gurtner and Reinhardt 2016). The novelty of content determines whether or not there will be a comparison between the new product and the existing products on the market. The search for information in the market influences the firm's 
capability in improving product content and in generating novelty. Therefore, it is necessary to address the nature of the content, technological and/or market, which must be incorporated into the new products.

\subsubsection{Technological Content}

Technological changes can be sustained, and they are characterized by providing new features, new benefits or improvements in already existing technology, the latter being called incremental innovations (Christensen 1997; Garcia and Calantone 2002; Gurtner and Reinhardt 2016). On the other hand, disruptive technological changes are characterized by new technologies that offer a different package of attributes that will characterize a new market (Christensen 1997). Technological changes, incremental or disruptive, play a fundamental role in both existing firms and for generating new ones.

Authors such as Lall (1992) and Bell and Pavitt (1995) described different technological capabilities [low, medium, and high] according to different abilities performed by firms in order to achieve a technological novelty. By including non-technological capabilities, Zawislak et al. (2012, 2013) proposed an approach with four key capabilities: development, technological, transactional and market. In this model, the development capability and the transactional capability are the main drivers of the new product development process. These two capabilities define a firm's ability to handle the new products (Alves et al. 2017).

The technological novelty embraces new technological knowledge and the search for new possibilities (Kim et al. 2013). This is the dominant method in science-oriented firms (Stefik and Stefik 2004). The researcher works to solve a problem even before any consumer demonstrates needs. Content can be obtained in three ways: of information and knowledge from a theory [theory-driven]; of a set of data that can be analyzed [data-driven]; or by using a new analytical method [method-driven] (Stefik and Stefik 2004). This type of firm has the ability to acquire substantial technological knowledge by regularly seeking information on technological opportunities and threats, as well as internally exploiting this knowledge in their development activities by considering technology as their main strategic input (Slater et al. 2014). They are constantly updating their technological content.

\subsubsection{Market Content}

The market novelty embraces new market knowledge and the search for new consumer's needs [need-driven]. These needs are identified in the market by reporting actual and existing problems (Stefik and Stefik 2004) which offers opportunities for the products in the short term. The objective of the research is to find a solution to a consumer's real problem. This perspective is the dominant method for engineering-oriented firms (Stefik and Stefik 2004). The answers to what is needed are more related to the market content. The market solutions tend to be imitation.

Firms can seek novelties in the market in three ways (Slater et al. 2014): by self-learning, by focusing on the market learning, and by focusing on the customer. Learning itself creates values that include a commitment to learning, open-mindedness and the sharing of market principles, ideals, and beliefs (Baker and Sinkula 2002). The open-mindedness is related to the unlearning construct and supports the proactive questioning of the value of routines, assumptions, and long-lasting beliefs. This is critical to the development of radical innovations in products (Slater et al. 2014).

Market learning can be done by exploration or exploitation. In the exploratory approach, the market the information must go beyond the knowledge of the products on the market (Kim and Atuahene-Gima 2010), increasing the innovativeness (Molina-Castillo et al. 2011). In the exploitative, learning focuses on improving and extending the information that has already been acquired, improving cost-effectiveness (Kim and Atuahene-Gima 2010) and quality (Molina-Castillo et al. 2011) of the products. These approaches improve product satisfaction (Kim et al. 2013). The strong market orientation allows firms to be better suited to the activities of the marketing mix. These activities support the launch of new products (e.g., channel management, sales force training, customer service, sales promotion programs, advertising) (Baker and Sinkula 2007; Molina-Castillo et al. 2011). 
The market and client approach can be responsive [competitor driven], proactive [company driven] or both (Baker and Sinkula 2002; Slater et al. 2014). Responsive firms specifically focus on meeting existing customer needs with current technologies. Firms that develop advance intelligence to enable the identification of emerging or latent customer needs have a proactive customer orientation. The generation of anticipated intelligence allows the firm to proactively seek the market for opportunities that are not evident to competitors. Latent needs are real needs that are not yet in a customer's consciousness, so they cannot articulate them (Baker and Sinkula 2002; Slater et al. 2014).

In sum, the content incorporated into the new products will be the result of the search outside the firm's borders. This search could be by technology (technology scanning) or by market information (commercial scanning) or both (Stefik and Stefik 2004; Jeong et al. 2006; Kim et al. 2013). Therefore, the novelty depends on the nature of the content that will be incorporated into the new product-technological, marketing or both. The contents should be incorporated into the product in the stages of new product development. This combination is particularly important for knowledge-based industries.

\subsection{New Product Development}

Researchers in this area agree that there isn't a consolidated "body of theory" of New Product Development [NPD]. Loch and Kavadias (2008) propose that there is a rigorous theoretical structure that could encompass NPD as a whole-multi-level evolutionary theory. NPD encompasses a large number of topics and challenges in a firm, such as a strategy formulation, deployment, resource allocation, and coordinated collaboration among people of different professions and nationalities, and includes systematic planning, monitoring, and control.

Creating a new product is a multidisciplinary effort that involves several functional departments (Brettel et al. 2011). Research findings on cross-functional integration in NPD projects appear to agree that Research and Development [R\&D], marketing, and manufacturing are the three main contributors to this process. Teams are involved in various interdependent tasks. For example, marketing and manufacturing are dependent on $R \& D$ to understand the technological potential of a product. Moreover, marketing's interpretation of customer preferences leads to numerous product features that R\&D has to consider during product development (Brettel et al. 2011).

Considering the multidisciplinary of NPD and instead of focusing on the process efficiency, we used the new product development approach based on evolutionary theory to describe the conception, operationalization and launching of new products, and their novelty. Loch and Kavadias (2008) define NPD as the activities of the firm that lead to a stream of new or changed product market offerings over time. The process of developing products encompasses the generation of ideas, selection and transformation into artifacts (manufactured products) and activities (services) offered to the customers. In this approach, the NPD stages are conception, operationalization, and launch.

\subsubsection{Conception}

The conception stage includes the idea generation process by variation and selection. The idea generation or ideation is a variant generation process, which identifies new combinations of technologies, processes, and market opportunities with the potential to create economic value (Gurtner and Reinhardt 2016). Variants are generated by directed search and 'blind' combination of unrelated elements such as creativity (Flemimg and Mingo 2008). After searching for various ideas, it is necessary to select them. The selection process includes choosing the most promising ideas among the new combinations for further investment (of financial, managerial, physical, and/or human resources) according to the consistent criteria (Loch and Kavadias 2008). This stage represents greater abstraction (Gurtner and Reinhardt 2016) such as the research function of R\&D department (Ilori et al. 2000). In this approach, the most important aspects include evaluating the quality and quantity of ideas (Gurtner and Reinhardt 2016) that are available to form the new product concept. 


\subsubsection{Operationalization}

The operationalization stage is the development of the new product concept. It is a transformation process, which converts opportunities into economic goods and codified knowledge (embodied in a design). It is an applied stage by transforming ideas into artifacts such as prototypes (Ilori et al. 2000; Flemimg and Mingo 2008). This stage includes technology transfer, portfolio management, experimentation and tests, and it represents the product development such as the development function of R\&D department. Having a formalized and structured NPD is widely accepted as the best practice for developing products by increasing process efficiency (Holahan et al. 2014) and creating routines. Development routines tend to repeat the same patterns, and risk not creating novelties. The novelty may be reached in the adjustments of faults.

\subsubsection{Launch}

The launch is the stage of translation of market needs. It is often considered the most expensive and risky stage, and the least well managed part of the NPD process. It includes the planning of the marketing activities (identifying the target markets; establishing a marketing mix; predicting financial results; establishing a control and adjustment system) and the services offered to the customers (Slater et al. 2014). The role of the launch stage is to maximize the chances of profitability reached by the acceptance of the target market through innovativeness (Baker and Sinkula 2007; Molina-Castillo et al. 2011). It includes the product preparation for commercialization. This stage represents marketing function and the novelties may come from the translation of the firm's market knowledge.

Considering that a firm develops more than one product, the new products developed by a firm are not homogeneous. Even if the firm has the full capability to do so, neither the firm's stock of knowledge will be incorporated into the content of each new product nor will it be followed in the same way. Then, it is necessary to identify the differences between the new products in relation to their innovativeness.

\subsection{Product Innovativeness}

A plethora of definitions for innovation has resulted in ambiguity in such a way that the terms 'innovation' and 'innovativeness' are operationalized and used in the NPD literature with very similar meanings (Garcia and Calantone 2002). When terms like these are used as interchangeable concepts, inconsistencies in construct definitions cause inconsistencies in the results (Garcia and Calantone 2002; Schultz et al. 2013). Garcia and Calantone (2002, p. 113) define product innovativeness as "a measure of the potential discontinuity that a product [process or service] can generate in the marketing and/or technological process". It represents the degree of novelty, in another word, how different or disruptive the product is, when compared to other products in the market. It is a performance measure related to the product characteristics, a non-financial measure. Schultz et al. (2013) argue that innovativeness is a continuous construct and can be measured. Innovativeness is set in a continuous range from the lowest to the highest. The imitation of proven practices, where knowledge is widespread, and the degree of novelty is low, gives the product low innovativeness (Lall 1992). Significant improvements on technology or new applications necessarily present more degree of novelty (Lall 1992) than imitation and, consequently, it increases the product innovativeness. The highest product innovativeness is related to the introduction of new technology in new markets (Garcia and Calantone 2002; Stefik and Stefik 2004).

As there are differences between the technological and market characteristics regarding the impact of novelty and based on Garcia and Calantone (2002) typology, Schultz et al. (2013) propose a product innovativeness typology based on technological innovativeness and market innovativeness (Figure 1). 


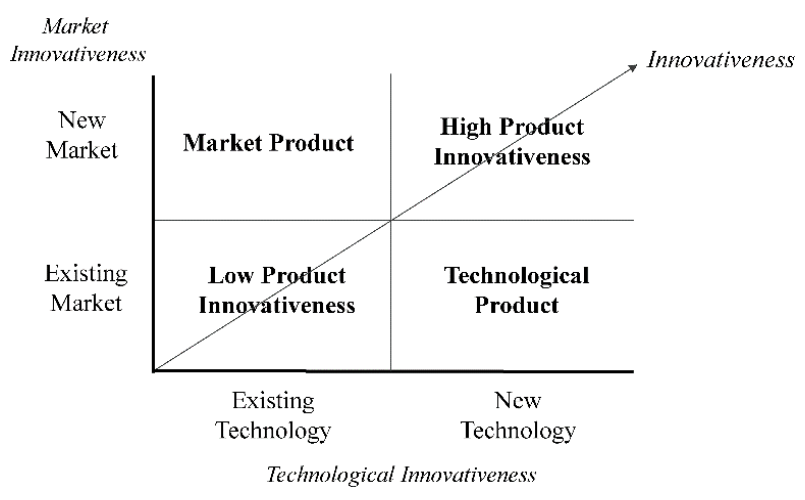

Figure 1. Product innovativeness typology (Schultz et al. 2013).

Technological innovativeness implies that the introduction of new technological principles requires a new knowledge base, allowing for the realization of significant performance jumps, fundamental changes in the architecture of a technological system, or the use of new components and modules (Schultz et al. 2013).

The market facet of innovativeness relates to the changes new products cause within the market. A central criterion of market innovativeness is whether the innovation proposes a significant change in customer value in comparison to the prior products (Chandy and Tellis 1998). This can be the fulfillment of previously unsatisfied needs and/or the creation of new customer benefits, which may change market structures and address a new customer base. In extreme cases, a new product represents the one that establishes a new product category or create a completely new market (Schultz et al. 2013) such as the green products.

\section{Brazilian Cosmetics Industry and the Innovativeness Context}

The cosmetics industry is a worldwide knowledge-based sector. Cosmetics companies launch a great number of new products around the world. Brazil was the fourth largest cosmetics consumer market in 2016 and the second industry with the most investments for innovation in Brazil (ABIHPEC Associação Brasileira da Indústria de Higiene Pessoal, Perfumaria e Cosméticos). However, it prevails routine-only product innovation in Brazilian cosmetics industry to maintain competitiveness (Barbieux et al. 2013). Even in Brazil, there is a regulatory agency for the cosmetics industry, yet, there is still no regulation framework for nanotechnology. Firms that develop or use nanotechnology follow international regulation such as the European regulation. The main regulations are about the size (particles less than $100 \mathrm{~nm}$ ), nature of ingredients (biodegradable) and efficiency (more than non-nanometric ingredients).

The industry structure and the availability of resources influence the kind of new firms that enter the industry and the type of innovations they follow and the knowledge intensity (Loch and Kavadias 2008). Barbieux et al. (2013) argue that one of the problems to innovate in Brazilian cosmetics industry is the $R \& D$ team background. The team's low quality of scientific and technological background reflects on low knowledge-processing capability and it results merely in products improvements (Barbieux et al. 2013). This finding is in line with the results of Escribano et al. (2009), in which the low-quality inputs into the innovation process reveals a firm's inability to innovate. In addition, according to Todtling et al. (2009) the type of external knowledge accessed and its knowledge-processing capacity limit technological changes and, consequently, the product development (Barbieux et al. 2013).

To seek product innovativeness in Brazilian cosmetics industry, we chose to research nanotechnological products. The nanotechnology has been the latest technology and novelty on new products in the cosmetic industry (ITEHPEC Instituto de Tecnologia e Estudos de Higiene Pessoal). Also, it has been included in government strategic agenda in order to support the indigenous technology and innovation. 


\section{Research Method}

Firstly, an electronic search was run on the Web of Science platform using pre-selected criteria based on acronym PICO ${ }^{1}$ (Higgins and Green 2011) adapted for Social Sciences. The groups of research, data collection, criteria of variables inclusion and exclusion were validated by two experts (on Innovation) at Aston University (UK) to refine the product innovativeness dimensions. In addition, we explored the Handbook of New Product Development Management (Loch and Kavadias 2008) to support the NPD approach based on the evolutionary perspective.

Due to the inconsistencies on approaches for measuring Product Innovativeness from the firm's perspective, we decided to use the typology suggested by Garcia and Calantone (2002). This approach differentiates the Market Product and Technological Product by understanding that they have a different impact on the market.

For the empirical work and in order to explore the highest Product Innovativeness, we chose two Brazilian emblematic cases recommended by Yin (2015). They are companies from cosmetic industry and use nanotechnology in their products.

To select cases and products, two industrial pharmacists and one expert on innovation in the pharmaceutical industry were consulted. In addition, we sought information on websites of Brazilian nanotechnology companies. The objective was to categorize the main product in the highest product innovativeness (technological and market) and to relate them to the respective product development. It was the two companies and their owners that were interviewed in April/May 2016.

The interviews were recorded and transcribed. The information was organized into an excel table so that it could be compared and analyzed. Content analysis followed the precepts proposed by Bardin (2016). As a result, it was possible to identify the level of innovativeness in their products and to describe the paths and challenges for nanotechnology-based cosmetics development in Brazil.

\section{Reporting the Nanotechnology Cases}

Located in the south of Brazil, NanoRS and NanoSC are Small and Medium Enterprises (SMEs) and renowned suppliers for the cosmetics industry. They started their activities in 2007/2008. The product portfolio of both companies uses nanotechnology as the main technology. The main characteristics of the companies are shown in Table 1.

Table 1. The main characteristics of NanoRS and NanoSC.

\begin{tabular}{lll}
\hline & NanoRS & NanoSC \\
\hline $\begin{array}{l}\text { Interviewee } \\
\text { Size }\end{array}$ & Technical Director (owner) & Technical Director (owner) \\
No. Employees & Small * & Small \\
People involved in Research, & 12 & 35 \\
R\&D or New Products & 1 on Research (New Products) & 5 on Research (New Products) \\
Patents & & 10 on R\&D \\
Founded in ... & No for option & Yes Marketing \\
Products (main segment) & 2008 & 2007 \\
$\begin{array}{l}\text { Products Portfolio (number) } \\
\text { Foreign market }\end{array}$ & nanoparticles for cosmetics & nanoparticles for cosmetics and textile \\
& 40 & 60 (selecting for decreasing to 35) \\
\hline
\end{tabular}

* After the interview, the company was sold to a UK multinational (July/2016).

NanoRS is smaller than NanoSC in the number of employees and also in the number of people working on the new products development team. While NanoSC has five, NanoRS has only one pharmacist. In addition, the NanoRS pharmacist, in fact, has many other activities besides the

1 PICO: Population, Intervention, Comparison, Outcome. 
new products research and development. NanoSC has two marketing experts in the new products development team, while NanoRS does not have specialized professionals in the marketing area.

With regard to the location, there is a huge difference between the two companies. While NanoRS headquarter is located in private area without other companies and research centers nearby, the NanoSC is located in a science park at the Federal University. The university infrastructure and staff diversity and availability are the elements that contribute positively to the new product development and novelty.

\subsection{The Case of NanoRS Company}

\subsubsection{Novelty}

From its first years of existence, NanoRS has searched technology opportunities by developing nanoparticles in order to encapsulate cosmetic raw materials. They started the business exploiting nanotechnology by using only green appeal such as vegetable raw materials and water-soluble substances. During the initial stage, NanoRS obtained information and knowledge from a theory [theory-driven]. After that, they produced market discontinuities and generally applied their technological content in order to adapt new inputs for cosmetics by using their dominated technology.

NanoRS market content is based on customer orientation responsiveness. They have searched for market novelties by focusing on their clients. The clients are multinational companies and NanoRS searches the solution for its clients within its technological possibilities. NanoRS focuses specifically on meeting existing customer needs, characterizing the search for novelties as a "responsive" approach. The interviewee revealed that 'usually the ideas are not ours'.

\subsubsection{New Product Development}

- Ideation (variation and searching ideas): The ideas variation occurs by searching international trends on fairs and by solving ordinary problems. NanoRS has done in-house brainstorming. The ideas selection is defined by excluding some types of raw material that are not of interest to the company. The interviewee commented that "[ ... ] at the first fair we went to, we made two products, put a lot of samples in our pocket, printed three or four folders and went to the market and beat the booth at the booth, offering to make our product".

- Operationalization: NanoRS makes formulations, pilots and the required tests. At NanoRS, the development stages are performed by the pharmacist, the R\&D person. However, the pharmacist time is not exclusive to the development of new products.

- Launch: For NanoRS, marketing is not very necessary and if the company needs it, it hires experts in the market place. The interviewee said that "who will consume my product is an industry. I do not have to worry about being attractive. I need to worry about doing a scientific marketing". So, the product launch is based on scientific marketing and B2B on fairs (national and international) and there is no marketing staff.

\subsubsection{Product Innovativeness}

For NanoRS, the success factors are related to the information disclosed from the client, the product positioning and the effectiveness. NanoRS achieves sole technology innovativeness by using nanoparticles for cosmetics with known use indication.

\subsection{The Case of NanoSC Company}

\subsubsection{Novelty}

NanoSC products content is based on technological orientation. The company searches new technology opportunities on theory [theory-driven] by regularly developing cosmetic nanoparticles not only for cosmetics but also for other industrial sectors such as textile industry. NanoSC has 
adapted and exploited cosmetics nanotechnology and green technology by applying them to fabrics and other materials.

NanoSC market content is based on learning orientation. Even if NanoSC searches for solutions for its clients within or without its own technological possibilities, its greater effort is to map and search international trends to exploit them. NanoSC has searched for market novelties by challenging concepts and looking for latent needs. The interviewee revealed that they "have an intensive internal work to map and identify international trends'.

\subsubsection{New Product Development}

- Ideation (variation and searching ideas): The idea variation occurs by searching on scientific articles. For two years, NanoSC worked on concepts of the new products. They studied the possibilities for these new products. The interviewee commented that: " $[\ldots]$ the first two years of the company were focused on these studies. We have come to all the benefits that we could exploit, the differentials of the technology we were proposing. It was based largely on what was scientifically prescribed and with revealed evidence $[\ldots]$. The ideas selection is defined by the expected performance of the new products.

- Operationalization: NanoSC makes formulations, pilots and the required tests. NanoSC has a $R \& D$ team that is divided into activities and is coordinated and guided by the pharmacist responsible for R\&D. The team is exclusively dedicated to product development.

- Launch: For NanoSC, the "marketing responsibility is focused on capturing trends and demands" and "receives [the marketing] information from the R\&D team to establish the product content." The launch is based on marketing intelligence and marketing mix. The new products launch is carried out in national and international fairs. In addition, the company markets technology such as reverse innovation. In this case, reverse innovation occurs in two ways-through clients that are multinational and transfer Brazilian technology to the parent or other subsidiaries or through foreign customers who buy directly from NanoSC.

\subsubsection{Product Innovativeness}

NanoSC achieves both technology and market innovativeness by using cosmetics' nanoparticles in new applications for products and industries with dermato-cosmetic properties. NanoSC states that success factors are related to the effectiveness, coupled with the short period to see the product results. "Our technology is not for any kind of product, it's for a company that seeks to add value in the product." As an indicator, it uses the repurchase. NanoSC states that "products with repurchase, we know we are right in positioning.". The summary of NanoRS and NanoSC innovation practices is shown in Table 2.

Table 2. The summary table of NanoRS and NanoSC.

\begin{tabular}{lll}
\hline \multicolumn{1}{c}{ Nano RS } & \multicolumn{1}{c}{ Nano SC } \\
\hline Novelty & \multicolumn{1}{c}{$\begin{array}{l}\text { technological orientation: search } \\
\text { technology opportunities inside the } \\
\text { known technology (nanotechnology } \\
\text { and green technology) }\end{array}$} & $\begin{array}{l}\text { technological orientation: search new } \\
\text { technology opportunities on theory such as } \\
\text { nanotechnology and green technology, learn } \\
\text { and apply for other industries }\end{array}$ \\
\hline Market Content $[\mathrm{MC}]$ & customer orientation responsive & learning orientation: challenges concepts \\
\hline
\end{tabular}


Table 2. Cont.

\begin{tabular}{lll}
\hline NPD & \multicolumn{1}{c}{ Nano RS } & \multicolumn{1}{c}{ Nano SC } \\
\hline \multirow{2}{*}{ Ideation } & $\begin{array}{l}\text { ideas variation: search } \\
\text { international trends on fairs and } \\
\text { ordinary problems by doing } \\
\text { in-house brainstorming }\end{array}$ & $\begin{array}{l}\text { ideas variation: scientific search on articles to } \\
\text { solve scientific problems two years by } \\
\text { conceptualizing new products }\end{array}$ \\
\cline { 2 - 3 } & $\begin{array}{l}\text { ideas selection: by exclusion of } \\
\text { ingredients }\end{array}$ & $\begin{array}{l}\text { ideas selection: by performance of } \\
\text { allowed ingredients }\end{array}$ \\
\hline Operationalization & performed by the pharmacist & performed by the R\&D department \\
\hline \multirow{2}{*}{ Launch } & $\begin{array}{l}\text { based on scientific marketing } \\
\text { and B2B on fairs (there is no } \\
\text { marketing staff) }\end{array}$ & $\begin{array}{l}\text { based on marketing intelligence and } \\
\text { marketing mix. }\end{array}$ \\
\cline { 2 - 3 } Product Innovativeness & $\begin{array}{l}\text { sells nanotechnology (Reverse Innovation: } \\
\text { from BR to the world) }\end{array}$ \\
\hline Results (How do they measure?) & $\begin{array}{l}\text { solely technology innovativeness } \\
\text { by using nanoparticles for } \\
\text { cosmetics with known } \\
\text { use indication }\end{array}$ & $\begin{array}{l}\text { technology and market innovativeness by } \\
\text { information clarity and sales) } \\
\text { applications such as fabrics with } \\
\text { dermato-cosmetic properties }\end{array}$ \\
\hline
\end{tabular}

\section{Discussion}

\subsection{Paths of Nanotechnology-based Cosmetics Development in Brazil}

During the initial years NanoRS and NanoSC obtained information and knowledge from a theory, aligned with Stefik and Stefik (2004) findings. NanoRS follow the strategy of exploiting known techniques available in the marketplace for this new technology. NanoSC has been acquiring substantial new technological knowledge by regularly seeking information on technological opportunities and threats. NanoSC exploits internally this knowledge in its development activities by considering technology as the main input for its strategy, such as suggested by Slater et al. (2014).

NanoSC demonstrated stronger technology orientation than NanoRS. The consequence of this is that NanoSC is more focused on the internal development, whereas the NanoRS is more focused on the requests of the clients. The location also reinforces the difference between the two companies. The university infrastructure and the quality of staff are factors that reflect positively on the new products development at NanoSC.

The two companies, NanoSC and NanoRS, have the conceptualization stage. The difference is that NanoSC spent two years studying and learning about the several possibilities of the new technology and NanoRS has developed two products that have been in the market and is not "opening the mindset" to the possibilities.

Both companies make formulations, pilots and the required tests. However, NanoSC has a team coordinated and guided by the responsible for R\&D. This work division allows having a greater number of projects in parallel, besides the team itself being more dedicated to the projects.

At the operationalization stage, skills are required from several people, each contributing to product testing and refinements (Stefik and Stefik 2004). Each mandatory test by regulation must be performed, not generating differentiation between firms. However, with each "adjustment," there is an opportunity to add something new to the products.

Both companies use national and international fairs to launch and market their products. As suppliers of raw material for the industry, marketing is B2B and both bet on scientific marketing. The difference is the importance given to the marketing department and consequently, the market content generated. Both cases are using nanotechnology as technological content, but they used different market contents. 
NanoSC states that "We are in the cosmetic, textile and we are already entering other segments in the R\&D phase, and soon we will be in the market. So, the capacity for innovation is very broad. In fact, by encapsulating the technology and certain assets we have, we reached a scope that we would not be able to achieve before". As illustrated in Table 2, it can be seen that NanoSC is constantly learning about products, using market information more efficiently, and is open-minded to take on new challenges.

Path 1: Learn about new technology, accumulate new knowledge, apply new technology, improve new products, and keep the technology learned.

Path 2: Learn about new technology, accumulate new knowledge, apply new technology, learn about new products, improve and apply the new technology learned in another sector through new products, sell own technology.

\subsection{Challenges of Nanotechnology-Based Cosmetics Development in Brazil}

Even if nanotechnology is a new technology worldwide, it is not guaranteed as an innovation. As a new technology, it requires new knowledge and research vocation in order to develop new products. NanoRS develops products based on customer orders. This decision affects the product innovativeness and also limits the application of nanotechnology for cosmetics only. In addition, the equipment and tests involving the new technology are rare and expensive. Despite the governmental incentives in Brazil, it is up to the companies to make the most of the incentives and to plan for their best use of the new products.

Challenge 1-Research Vocation: New technologies require new knowledge and people who are prepared to deal with it. To overcome the challenge: NanoSC, in addition to having a team of a greater number of experts, it is located in a university science park. The proximity to the university creates a natural environment for research. On the other hand, NanoRS is located in a private building, which involves more management problems characterized by the challenges for small businesses and undermines the research environment.

Challenge 2-Financial Resources: Governmental Incentives Management. To overcome the challenge: NanoSC, used the incentives to discover various properties that nanotech offered, had numerous possibilities for the commercial application of its products. NanoRS used incentives to support the development of new products from start to finish, and experienced budget constraints, restricting product development to existing applications in cosmetics.

Challenge 3-Prejudice: New Technologies "Made in Brazil". To overcome the challenge: There is prejudice against nanotechnology "Made in Brazil", as stated by the NanoSC interviewee. For NanoSC, "The fact of being from Brazil we noticed that it has a certain prejudice. So, the fact that we have a plant in Switzerland, which is what we are doing this year, will facilitate having a Brazilian technology, produced in Switzerland and spraying all over Europe". NanoRS is preparing the company to sell for a multinational group.

\section{Concluding Remarks and Conceptual and Managerial Implications}

The search for novelty is permanent. Both NanoRS and NanoSC claim that they "breathe and live on innovation" and that the businesses of the companies should seek novelties to develop new products. Even the nanotechnology, which is considered "high technology", is not a guarantee of innovation. The combined effort with the market novelties is necessary. It is necessary to aggregate marketing innovations from exploratory searches or marketing approaches, to reach new needs or new markets, which gives high product innovativeness.

The NPD evolutionary approach based on variation and selection is unusual but can be useful when the focus is on novelty instead of efficiency. The change of focus was only possible by the theoretical contribution of evolutionary theory to the theme of NPD (Loch and Kavadias 2008). The contribution of evolutionary theory ends up reinforcing the importance of the NPD conceptualization stage, which is often neglected in firms. The "world of ideas" or generation of ideas plays a fundamental role in the 
generation of product innovation (Gurtner and Reinhardt 2016), which was found in current research. For the practitioners searching for innovation on products, the focus of NPD should be on novelty and in the ideas and concept stages, instead of time and efficiency.

NanoRS and NanoSC presented similar operationalization and launch on new product development but had a different focus on conception. Even if both cases developed nanotechnology-based products, NanoSC shows more potential attributes for the final products in the conception phase. The result is that the company stands out internationally for innovative products. Also, it will produce Brazilian nanotechnology for cosmetics, food and textile sectors in Europe. The NanoRS restricted the conception phase to develop products based on customer orders.

The NPD conception stage has proved to be important for both technological and market contents, and for impacting product innovativeness. Learning creates values that include the commitment to learning, open-mindedness and the sharing of market principles, ideals, and beliefs (Baker and Sinkula 2002). The open-mindedness is related to the unlearning construct and supports the proactive questioning of the value of routines, assumptions, and long-lasting beliefs. This is critical to the development of radical innovations in products (Slater et al. 2014).

This research has some limitations. It is exploratory work, and further research is needed to validate the approach, the dimensions, and the variables to propose a scale that can measure the intensity of novelty in products.

Author Contributions: The research was developed by D.B. and oriented/supervised by A.D.P.

Funding: The present study was carried out with the financial support of the Brazilian Government research funding agencies: Coordination for the Improvement of Higher Level or Education Personnel (CAPES) and the Brazilian National Council for Scientific and Technological Development (CNPq).

Conflicts of Interest: The authors declare no conflict of interest.

\section{References}

ABIHPEC (Associação Brasileira da Indústria de Higiene Pessoal, Perfumaria e Cosméticos). 2017. Panorama do Setor 2017. Available online: https:/ / abihpec.org.br/publicacao/panorama-do-setor-2017/ (accessed on 18 December 2017).

Alves, André Cherubini, Denise Barbieux, Fernanda Maciel Reichert, Jorge Tello-Gamarra, and Paulo Antônio Zawislak. 2017. Innovation and Dynamic Capabilities of the Firm: Defining an Assessment Model. Revista de Administração de Empresas 57: 232-44. [CrossRef]

Baker, William E., and James M. Sinkula. 2002. Market Orientation, Learning Orientation and Product Innovation. Journal of Market-Focused Management 5: 5-23. [CrossRef]

Baker, William E., and James M. Sinkula. 2007. Does Market Orientation Facilitate Balanced Innovation Programs? An Organizational Learning Perspective. Journal of Product Innovation Management 24: 316-34. [CrossRef]

Barbieux, Denise, Paulo Antonio Zawislak, and Fernanda Maciel Reichert. 2013. Innovative Performance in Brazilian Cosmetics Industry. Paper presented at 11th Globelics Conference, Ankara, Turkey, September $11-13$.

Bardin, Laurence. 2016. Análise de Conteúdo. São Paulo: Edições, Volume 70.

Bell, Martin, and Keith Pavitt. 1995. The development of technological capabilities. In Trade, Technology and International Competitiveness. Edited by Irfan-ul-Haque. Washington: The World Bank, pp. 69-101.

Brettel, Malte, Florian Heinemann, Andreas Engelen, and Steven Neubauer. 2011. Cross-functional integration of R\&D, marketing, and manufacturing in radical and incremental product innovations and its effects on project effectiveness and efficiency. Journal of Product Innovation Management 28: 252-69.

Chandy, Rajesh K., and Gerard J. Tellis. 1998. Organizing for Radical Product Innovation: The Overlooked Role of Willingness to Cannibalize. Journal of Marketing Research 35: 474-88. [CrossRef]

Christensen, Clayton M. 1997. The Innovator's Dilemma. Boston: Harvard Business School Press.

Cohen, Wesley M., and Daniel A. Levinthal. 1990. Absorptive capacity: A new perspective on learning and innovation. Administrative Science Quarterly 35: 128-52. [CrossRef] 
Dosi, Giovanni. 1988. The nature of the innovative process. In Technical Change and Economic Theory. Edited by Giovanni Dosi, Christopher Freeman, Richard Nelson and Luc Soete. London: Pinter.

Eisenhardt, Kathleen M., and Jeffrey A. Martin. 2000. Dynamic capabilities: What are they? Strategic Management Journal 21: 1105-21. [CrossRef]

Escribano, Alvaro, Andrea Fosfuri, and Josep A. Tribó. 2009. Managing external knowledge flows: The moderating of absorptive capacity. Research Policy 38: 96-105. [CrossRef]

Figueiredo, Paulo N. 2004. Aprendizagem tecnológica e inovação industrial em economias emergentes: Uma breve contribuição para o desenho e implementação de estudos empíricos e estratégias no Brasil. Revista Brasileira de Inovação 3: 323-62. [CrossRef]

Flemimg, Lee, and Santiago Mingo. 2008. Creativity in new product development: An evolutionary integration. In Handbook of New Product Development Management. Edited by Christoph Loch and Stylianos Kavadias. Burlington: Elsevier, pp. 113-33.

Garcia, Rosanna, and Roger Calantone. 2002. A critical look at technological innovation typology and innovativeness terminology: A literature review. Journal of Product Innovation Management 19: 110-32. [CrossRef]

Gurtner, Sebastian, and Ronny Reinhardt. 2016. Ambidextrous Idea Generation-Antecedents and Outcomes. Journal of Product Innovation Management 33: 34-54. [CrossRef]

Higgins, Julian P. T., and Sally Green. 2011. Cochrane Handbook for Systematic Reviews of Interventions. version 5.1.0; London: The Cochrane Collaboration, Available online: http:/ /handbook.cochrane.org/ (accessed on 10 November 2014).

Holahan, Patricia J., Zhen Z. Sullivan, and Stephen K. Markham. 2014. Product Development as Core Competence: How Formal Product Development Practices Differ for Radical, More Innovative and Incremental Product Innovations. Journal of Product Innovation Management 31: 329-45. [CrossRef]

IBGE (Instituto Brasileiro de Geografia e Estatística). 2016. Pesquisa de Inovação-PINTEC 2014; Rio de Janeiro: IBGE.

Ilori, M. O., J. S. Oke, and S. A. Sanni. 2000. Management of new product development in selected food companies in Nigeria. Technovation 20: 333-42. [CrossRef]

ITEHPEC (Instituto de Tecnologia e Estudos de Higiene Pessoal). 2013. Nanotecnologia em Cosméticos: Documento de Referência. São Paulo: Agosto.

Jeong, Insik, Jae H. Pae, and Dongsheng Zhou. 2006. Antecedents and consequences of the strategic orientations in new product development: The case of Chinese manufacturers. Industrial Marketing Management 35: 348-58. [CrossRef]

Kim, Namwoon, and Kwaku Atuahene-Gima. 2010. Using Exploratory and Exploitative Market Learning for New Product Development. Journal of Product Innovation Management 27: 519-36. [CrossRef]

Kim, Linsu, and Richard R. Nelson. 2005. Tecnologia, Aprendizado e Inovação: A experiência das Economias de Industrialização Recente. Campinas: Editora Unicamp.

Kim, Namwoon, Subin Im, and Stanley F. Slater. 2013. Impact of Knowledge Type and Strategic Orientation on New Product Creativity and Advantage in High-Technology Firms. Journal of Product Innovation Management 30: 136-53. [CrossRef]

Lall, Sanjaya. 1992. Technological capabilities and industrialization. World Development 20: 165-86. [CrossRef]

Loch, Christoph H., and Stylianos Kavadias. 2008. Handbook of New Product Development Management. Burlington: Elsevier.

Molina-Castillo, Francisco-Jose, Daniel Jimenez-Jimenez, and Jose-Luis Munuera-Aleman. 2011. Product competence exploitation and exploration strategies: The impact on new product performance through quality and innovativeness. Industrial Marketing Management 40: 1172-82. [CrossRef]

Nelson, Richard R., and Sidney G. Winter. 2005. Uma Teoria Evolucionária da Mudança Econômica. Campinas: Unicamp.

Rush, Howard, John Bessant, and Mike Hobday. 2007. Assessing the technological capabilities of firms: Developing a policy tool. RED Management 37: 221-36.

Schultz, Carsten, Søren Salomo, and Katrin Talke. 2013. Measuring New Product Portfolio Innovativeness: How Differences in Scale Width and Evaluator Perspectives Affect its Relationship with Performance. Journal of Product Innovation Management 30: 93-109. [CrossRef]

Schumpeter, Joseph A. 1984. Capitalismo, socialismo e democracia. Rio de Janeiro: Zahar. First published 1942. 
Slater, Stanley F., Jakki J. Mohr, and Sanjit Sengupta. 2014. Radical Product Innovation Capability: Literature Review, Synthesis, and Illustrative Research Propositions. Journal of Product Innovation Management 31: 552-66. [CrossRef]

Stefik, Mark, and Barbara Stefik. 2004. Breakthrough—Stories and Strategies of Radical Innovation. Cambridge: The MIT Press.

Teece, David J. 2007. Explicating dynamic capabilities: The nature and microfoundations of (sustainable) enterprise performance. Strategic Management Journal 28: 1319-50. [CrossRef]

Teece, David J., Gary Pisano, and Amy Shuen. 1997. Dynamic Capabilities and Strategic Management. Strategic Management Journal 18: 509-33. [CrossRef]

Todtling, Franz, Patrick Lehner, and Alexander Kaufmann. 2009. Do different types of innovation rely on specific kinds of knowledge interactions? Technovation 29: 59-71. [CrossRef]

Yin, Robert K. 2015. Estudo de caso: Planejamento e métodos. Porto Alegre: Bookman.

Zahra, Shaker A., and Gerard George. 2002. Absorptive capacity: A review, reconceptualisation and extension. Academy of Management Review 27: 185-203. [CrossRef]

Zawislak, Paulo Antônio, André Cherubini Alves, Jorge Tello-Gamarra, Denise Barbieux, and Fernanda Maciel Reichert. 2012. Innovation Capability: from Technology development to Transaction Capability. Journal of Technology Management and Innovation 7: 14-27. [CrossRef]

Zawislak, Paulo Antônio, André Cherubini Alves, Jorge Tello-Gamarra, Denise Barbieux, and Fernanda Maciel Reichert. 2013. The Influence of the Internal Capabilities on the Innovation Performance of the Firm: A multiple case study investigation in Brazil. International Journal of Management 30: 329-48.

(C) 2018 by the authors. Licensee MDPI, Basel, Switzerland. This article is an open access article distributed under the terms and conditions of the Creative Commons Attribution (CC BY) license (http:/ / creativecommons.org/licenses/by/4.0/). 